\title{
Soil and leaf nutrient content of tree species support deciduous forests on limestone outcrops as a eutrophic ecosystem
}

\author{
Davi Rodrigo Rossatto ${ }^{1^{*}}$, Fabrício Alvim Carvalho ${ }^{2}$ and Mundayatan Haridasan ${ }^{3}$
}

Received: December 3, 2014 Accepted: February 9, 2015

\begin{abstract}
The leaf and soil nutrient status of plants has been used to infer structural and functional aspects at the ecosystem level. Such data are available for tropical and savanna systems growing on poor and acidic soils; however, information for species growing on eutrophic and basic soils is lacking. Deciduous tropical forest is one of the most endangered types of tropical forest, and despite the high level of attention aimed at it, little is known about the nutritional composition of its leaves. Here, we provided information on leaf nutrient content ratios and relationships for deciduous tree species growing on a limestone outcrop in Central Brazil. We compared our data on soil and leaf macronutrient concentration with previously published data from savannas and humid forests in the Neotropics. We found that deciduous forest tree species possessed elevated concentrations of $\mathrm{N}, \mathrm{K}$, and Ca compared with those of other forest and seasonal systems. The higher leaf $\mathrm{Ca}$ and $\mathrm{P}$ is due to the elevated $\mathrm{Ca}$ and $\mathrm{P}$ content in soils of deciduous forest. We discussed these findings in the light of soil aspects, functional adaptations, and priorities that should be given to the conservation and management of deciduous forest.
\end{abstract}

Keywords: calcium, deciduous forest, leaf nutrient, limestone outcrops, nitrogen

\section{Introduction}

Foliar nutrient concentration has been used as an important parameter to recognize critical processes of community assembly and species coexistence (Aerts \& Chapin III 2000). It has been used to understand leaf structure and function at the ecosystem level, which act as regulators of plant productivity, biomass accumulation, and decomposition (McLaughlin \& Wimmer 1999; Vitousek \& Sanford 1986; Bustamante et al. 2006; Wright et al. 2007). These processes are supposed to differ drastically between different vegetation types such as forests and savannas because these systems may be conditioned to different periods of seasonal drought, edaphic aspects, and even fire frequency (Pennington et al. 2006; Furley 2007; Haridasan 2008; Gotsch et al. 2010). Data on leaf nutrient concentration for tropical forests and savannas are available in the literature (Klinge et al. 1983; Vitousek \& Sanford 1986; Haridasan 2008), particularly for growing vegetation on poor and acidic soils. However, such information is lacking for mesotrophic forest areas, which appear scattered within the poor acid oxisols throughout the Brazilian territory (Haridasan \& Araújo 2005).

Seasonal deciduous tropical forests (SDTF or simply deciduous forest) occur in small areas in Central and South America (Miles et al. 2006), and they are commonly associated with the scattered distribution of calcareous rock outcrops in the Neotropics (eutrophic rocks) (SanchezAzofeifa et al. 2013). Because of this scattered pattern, deciduous forests are dispersed among other vegetation types, possessing boundaries with humid forests and seasonal savannas (Pennington et al. 2009). The majority of deciduous forests in Brazil appear in seasonal areas, which are subjected to a low amount of annual rainfall (less than $1000 \mathrm{~mm} /$ year). This seasonal pattern exposes the vegetation to a large period of drought, thus resulting in the selection of species in which the deciduous phenological pattern is dominant (Mooney et al. 1995; Oliveira-Filho et al. 2006). In addition to seasonal aspects, such forests occupy areas where the not well-developed and incipient soils hold elevated levels of macronutrients, particularly $\mathrm{Ca}$ and Mg (Furley \& Ratter 1988; Mooney et al. 1995; Haridasan

\footnotetext{
${ }^{1}$ Departamento de Biologia, Faculdade de Ciências Agrárias e Veterinárias, Universidade Estadual Paulista, Prof. Paulo Donatto Castellane s/n, Vila Industrial, 14884-900, Jaboticabal, SP, Brazil

${ }^{2}$ Departamento de Botânica, Instituto de Ciências Biológicas, Universidade Federal de Juiz de Fora, José Lourenço Kelmer, s/n, São Pedro, 36036-900, Juiz de Fora, MG, Brazil

${ }^{3}$ Departamento de Ecologia, Instituto de Ciências Biológicas, Universidade de Brasília, PO Box 04457, 70904-970, Brasília, DF, Brazil

*Corresponding author: drrossatto@gmail.com
} 
2008; Pennington et al. 2006). Soil conditions must be reflected in leaf nutrient concentrations (Kimmins 2003), which implies that the knowledge of such information can elucidate the characteristics of these systems accurately, as generally being composed of an exclusive flora (Furley \& Newey 1979; Felfili et al. 2007).

Somavilla et al. (2014), described the morphoanatomical leaf structure of deciduous forests species as mesomorphic because these species have thinner leaves at elevated values of specific leaf area $\left(80-270 \mathrm{~cm}^{2} \cdot \mathrm{g}^{-1}\right)$. Based on this information and taking into account the leaf economic spectrum (Wright et al. 2004) and the edaphic aspects of such systems (Pennington et al. 2006), one may expect elevated concentrations of macronutrients in leaves of deciduous forest species.

Here, we studied the concentrations and ratios of leaf nutrients in common tree species growing in a deciduous forest on limestone outcrops in Central Brazil. We also utilized previously published data on leaf nutrients for humid forests and savannas that occur among deciduous forests in Central Brazil (Furley 2007) to compare our data with the nutrient content of other types of humid forests in Brazil (Atlantic and Amazon forest). Our approach relies on comparisons of species exclusive for each environment only, which allows a fine comparison of nutritionally distinct groups of plants that should be formed exclusively by differences in edaphic conditions (Araújo \& Haridasan 1988). Because deciduous forests grow on limestone outcrops, we expect to find that deciduous forests show an elevated concentration of macronutrients in their leaves compared with that of other tropical ecosystems. Based on the analysis of distinct tropical forest and savanna ecosystems, we also hypothesized that nutrient concentrations in soils will be positively related with their concentrations in leaves of species at the community level (Kimmins 2003; Hardtle et al. 2005).

\section{Materials and Methods}

\section{Study site and species}

This study was performed in a patch of deciduous forest occurring in the northeastern region of Goiás State, Brazil, at "Fazenda Sabonete," municipality of Iaciara in the Paranã valley ( $\left.14^{\circ} 03^{\prime} 53.2^{\prime \prime} \mathrm{S}, 46^{\circ} 29^{\prime} 15.2^{\prime \prime} \mathrm{W}\right)$. The dominant vegetation type of this region is the savannas; however, deciduous, semi-deciduous, and evergreen gallery forests are also present (Silva et al. 2006). Savannas occur mainly on poor oxisols, whereas semi-deciduous and deciduous forests are restricted to shallow soils and limestone patches, respectively (Felfili et al. 2007). We sampled individuals from the more common and dominant species in the studied deciduous forest (Felfili et al. 2007). The selection was based on the availability of individuals and leaves at the studied site, taking into account the important value index obtained in the same study area by a previous phytosociological study
(Tab. 1) (Felfili et al. 2007). The selected species represent almost $70 \%$ of the total tree individuals with $\mathrm{DBH}>5 \mathrm{~cm}$ (Felfili et al. 2007)

\section{Sample collection and nutrient analysis}

Soil data for deciduous forests were retrieved from Carvalho (2009), where 25 soil samples were collected in the studied forest (twenty-five $20 \times 20 \mathrm{~m}$ plots, covering $1 \mathrm{ha}$ ). Data for soil samples were analyzed following EMBRAPA (1997) standard procedures. Leaves were collected in February 2009 from the boundaries of the crown in all studied trees, comprising three chosen individuals per species. We sampled completely expanded sunlit leaves, without any sign of senescence or herbivory damage, located at the second or third node from the branch tip. Three leaves were collected for each individual and were dried at $70^{\circ} \mathrm{C}$ for 3 days. The dried leaves were finely ground and a subsample was taken for macronutrient determinations $(\mathrm{N}, \mathrm{P}, \mathrm{K}, \mathrm{Ca}$, and $\mathrm{Mg}$ ). Total leaf $\mathrm{N}$ was determined in diluted acid digests using the micro-Kjeldahl procedure (Allen et al. 1974). Total extractable $\mathrm{P}$ was determined colorimetrically by complex formation with molibdovanadate according to Allen et al. (1974). K, Ca, and Mg were determined by atomic absorption after wet digestion with a tri-acid mixture of nitric, sulphuric, and perchloric acids (10:1:2).

\section{Data compilation and statistical analysis}

For comparisons of deciduous forest with other vegetation types, we assessed previously collected data for each type of vegetation that normally surrounds deciduous forest formations and also for other forest types appearing in the Atlantic and Amazon rainforests (Tab. 2). We selected studies reporting leaf and soil macronutrient concentrations for

Table 1. List of the studied tree species in a deciduous forest under limestone outcrops in Central Brazil. Data compiled from Felfili et al. (2007)

\begin{tabular}{lc}
\hline Species & Family \\
\hline Dilodendron bipinnatum Radlk. & Sapindaceae \\
Pseudobombax tomentosum (Mart. \& Zucc.) A.Robyns & Malvaceae \\
Myracrodruon urundeuva Allemão & Anacardiaceae \\
Cavanillesia arborea (Willd.) K.Schum. & Malvaceae \\
Acacia tenuifolia (L.) Willd. & Fabaceae \\
Combretum duarteanum Cambess. & Combretaceae \\
Tabebuia impetiginosa (Mart. ex A.DC.) Standley & Bignoniaceae \\
Sterculia striata A.St.-Hil. \& Naudin & Malvaceae \\
Aspidosperma subincanum Mart. ex A.DC. & Apocynaceae \\
Guazuma ulmifolia Lam. var. ulmifolia & Malvaceae \\
Commiphora leptophloeos (Mart.) J.B.Gillett & Burseraceae \\
Bauhinia ungulata L. & Fabaceae \\
Cnidoscolus vitifolius (Mill.) Pohl A. & Euphorbiaceae \\
\hline
\end{tabular}


Table 2. List of the studied vegetation types in the Neotropics. Data for leaf and soil nutrient content were compiled from the following references.

\begin{tabular}{cccc}
\hline Biome & Type of Vegetation & No Species & References \\
\hline Neotropical savanna & Savanna & 10 & Rossatto et al. (2013) \\
Neotropical savanna & Gallery Forest & 15 & Rossatto et al. (2010); Nogueira and Haridasan (1997) \\
Neotropical savanna & Semi-deciduous forest & 10 & Moreno (2005); Haridasan and Araujo (2005) \\
Neotropical savanna & Deciduous forest & 13 & This study \\
Atlantic rainforest & Primary rainforest & 11 & Boeger et al. (2005) \\
Atlantic rainforest & Secondary rainforest & 14 & Sambuichi (2003) \\
Amazon forest & "Terra Firme" forest & 12 & Klinge et al. (1983) \\
Amazon forest & "Várzea" forest & 15 & Klinge et al. (1983) \\
Amazon forest & "Igapó" forest & 14 & Klinge et al. (1983) \\
\hline
\end{tabular}

gallery forest (a humid forest appearing near small streams), semi-deciduous forest (seasonal vegetation growing on not well-developed soils), and savanna (seasonal vegetation growing on deep and well-drained soils). All the previously selected vegetation types appear in a climate similar to that where deciduous forest is found (Ribeiro \& Walter 2008) but differing in soil conditions. For the Atlantic rainforest (humid forest on deep and drained soils) (Morellato \& Haddad 2000), we selected one study dealing with two situations: in a primary Atlantic rainforest and in an agroforested system (Sambuichi 2003). Our samples of the Amazon rainforest included a "Terra firme" forest (humid tropical forest on deep and drained soils), an "Igapó" forest (seasonally flooded forest, poor in nutrients), and a "Várzea Forest" (seasonally flooded forest, rich in nutrients) (Pires \& Prance 1985). To make our data comparable, we selected studies that used a similar methodology to ours to estimate macronutrient concentrations in leaves and soils.

To compare average leaf macronutrient $(\mathrm{N}, \mathrm{P}, \mathrm{K}, \mathrm{Ca}$, and $\mathrm{Mg}$ ) concentrations at the community level between distinct vegetation types, we performed a multivariate analysis of variance (MANOVA) followed by Tukey's test because there is a strong correlation between leaf nutrients, particularly between $\mathrm{N}$ and $\mathrm{P}$ and $\mathrm{Ca}$ and $\mathrm{Mg}$ (Zar 2010). Values of leaf macronutrient concentrations for each species were used as replicates because we were interested in testing for differences between vegetation types. The number of replicates analyzed per vegetation varied from 10 to 15 (see Tab. 2). We performed a linear regression to test the relationships between soil nutrient content and leaf nutrient content at the community level. We used linear regression analysis to assess the position of each vegetation on a single axis of variation in an ecosystemic relationship between $\mathrm{N}$ and $\mathrm{P}$ and $\mathrm{Ca}$ and $\mathrm{Mg}$. In all cases, $\alpha$ was taken as 5\%.

\section{Results}

\section{Soil properties of studied ecosystems}

The incipient soils of deciduous forest had a $\mathrm{pH}$ value around six and elevated values of exchangeable $\mathrm{Ca}$ and $\mathrm{Mg}$ (Tab. 3) as well as higher values of exchangeable P (Tab. 3).
Deciduous forest soils were comparable to semi-deciduous forest soils in terms of $\mathrm{P}$ content. However, their elevated potential of Ca and Mg exchange is comparable only to "Várzea" forest soils (Tab. 3). Savanna and the other studied forest soils possessed higher iron and aluminum concentrations (Tab. 3).

\section{Leaf nutrient content in tree species of deciduous forest and other ecosystems}

Leaf macronutrient concentrations for deciduous forest tree species are shown in Table 4. Eight species showed $\mathrm{N}: \mathrm{P}$ ratios higher than 16 (Tab. 4), whereas two had values near 30 (25 for Guazuma ulmifolia and 30 for Cavanillesia arborea). None of the species studied had values lower than 14, and four of them had values between 14 and 16 .

We found significant differences in the concentration of leaf nutrients and N:P ratio in the evaluated vegetation types (MANOVA: Wilks $\lambda=0.056, \mathrm{df}=48, F=110.79$, $P<0.01)$. Compared to trees in other forest and savanna types, the deciduous tree species studied here showed higher values for almost all nutrients studied. $\mathrm{N}$ concentration for deciduous forest was around $2.4 \%$ and only semi-deciduous and "Várzea" forests had similar values for this and some other nutrients (Tab. 5). Ca concentration was elevated in deciduous forests compared with that of other systems because the leaf concentration reached 1.7\% (also similar with the value found for "Várzea" forest), which is far from the values found for other types of forest (less than $0.8 \%$ ) (Tab. 5). In contrast, $\mathrm{P}$ and $\mathrm{Mg}$ concentrations were higher for "Várzea" and secondary Atlantic rainforest than for deciduous forest (Tab. 5). N:P ratios were higher than 16 for all studied vegetations (Tab. 5).

\section{Relationships between soil and leaf nutrient content and between leaf nutrients in the studied systems}

We found significant positive relationships between soil $\mathrm{P}$ and plant leaf $\mathrm{P}$ concentration $\left(r^{2}=0.289, P=0.034\right)$ as well as between soil $\mathrm{Ca}$ and plant leaf $\mathrm{Ca}$ concentration $\left(r^{2}=0.76, P=0.003\right)$ (Fig. 1). However, these relationships were not significant for $\mathrm{K}\left(r^{2}=0.033, P=0.308\right)$ or $\mathrm{Mg}\left(r^{2}\right.$ $=0.00, P=0.589)$ concentration. 
Table 3. Average soil properties in the deciduous forest on limestone outcrops in Central Brazil and other vegetation types (see Table 2). Data presented here comprise only surface layer of soil profile (between $0-20 \mathrm{~cm}$ ). na = not available.

\begin{tabular}{|c|c|c|c|c|c|c|c|c|c|}
\hline \multirow[t]{3}{*}{ Vegetation } & \multicolumn{9}{|c|}{ Soil properties } \\
\hline & $\mathrm{pH}$ & O.M. & $\mathbf{P}$ & $\mathrm{Al}$ & $\mathbf{K}$ & $\mathrm{Ca}$ & $\mathrm{Mg}$ & $\mathrm{Fe}$ & $\mathrm{H}+\mathrm{Al}$ \\
\hline & & $\%$ & mg.dm ${ }^{-3}$ & \multicolumn{6}{|c|}{ cmol.dm ${ }^{-3}$} \\
\hline Deciduous forest & 6.64 & 5.80 & 2.14 & na & 0.43 & 14.65 & 5.86 & 30.45 & 4.38 \\
\hline Semi-deciduous Forest & 5.70 & 2.30 & 2.70 & 0.10 & 0.54 & 8.09 & 1.45 & na & 4.00 \\
\hline Gallery forest & 5.12 & 12.4 & 1.98 & 0.36 & 0.70 & 2.30 & 0.65 & 70.67 & 5.45 \\
\hline Savanna & 4.67 & 1.20 & 0.46 & 0.45 & 0.30 & 0.11 & 0.06 & 89.00 & 6.94 \\
\hline Primary rainforest & na & na & na & na & na & na & na & na & na \\
\hline Secondary rainforest & 5.00 & 1.80 & 1.70 & 0.25 & 0.25 & 4.03 & 3.04 & 70.54 & na \\
\hline "Várzea" forest & 4.91 & 1.12 & 0.84 & 0.23 & 0.18 & 22.60 & 1.80 & 54.60 & na \\
\hline "Terra Firme" forest & 4.30 & 1.80 & 0.70 & 0.45 & 0.23 & 0.11 & 0.11 & 45.43 & na \\
\hline "Igapó" forest & 4.01 & 3.62 & 0.75 & 0.80 & 0.17 & 1.90 & 0.09 & 47.43 & na \\
\hline
\end{tabular}

Table 4. Leaf nutrient concentrations on a dry mass basis $\left(\mathrm{g} \cdot \mathrm{kg}^{-1}\right.$, mean $( \pm$ S.E. $\left.)\right)$ and N:P ratio in leaves of deciduous forest tree species in Central Brazil.

\begin{tabular}{|c|c|c|c|c|c|c|}
\hline Species & $\mathrm{N}$ & $\mathrm{P}$ & K & $\mathrm{Ca}$ & $\mathrm{Mg}$ & $\mathrm{N}: \mathrm{P}$ \\
\hline D. bipinnatum & $22.64(0.30)$ & $1.24(0.04)$ & $7.88(0.21)$ & $14.44(2.9)$ & $1.38(0.01)$ & $15.74(0.80)$ \\
\hline P. tomentosum & $23.54(0.28)$ & $1.71(0.26)$ & $12.59(0.20)$ & $13.17(1.42)$ & $2.74(0.01)$ & $20.97(0.70)$ \\
\hline M. urundeuva & $20.90(0.28)$ & $1.38(0.35)$ & $7.47(0.12)$ & $15.95(3.5)$ & $2.05(0.05)$ & $19.67(0.51)$ \\
\hline C.arborea & $24.13(0.10)$ & $1.67(0.21)$ & $12.47(0.77)$ & $16.11(2.4)$ & $1.88(0.06)$ & $30.83(1.06)$ \\
\hline A. tenuifolia & $29.34(0.02)$ & $1.07(0.07)$ & $8.63(0.28)$ & $16.78(2.1)$ & $1.48(0.08)$ & $15.19(1.63)$ \\
\hline C. duarteanum & $24.10(0.23)$ & $2.41(0.12)$ & $6.41(0.33)$ & $15.48(3.4)$ & $2.00(0.12)$ & $17.95(1.53)$ \\
\hline T. impetiginosa & $22.84(0.06)$ & $1.29(0.19)$ & $12.13(0.37)$ & $19.07(6.9)$ & $1.78(0.04)$ & $18.25(2.28)$ \\
\hline S. striata & $23.84(0.23)$ & $1.57(0.07)$ & $9.69(0.04)$ & $7.63(0.45)$ & $3.60(0.01)$ & $17.60(0.97)$ \\
\hline A. subincanum & $17.84(0.03)$ & $1.02(0.15)$ & $14.01(0.74)$ & $22.66(3.4)$ & $2.26(0.04)$ & $13.92(1.44)$ \\
\hline G. ulmifolia & $22.45(0.12)$ & $1.14(0.07)$ & $12.27(0.02)$ & $19.55(1.9)$ & $1.95(0.01)$ & $24.39(2.59)$ \\
\hline C. leleptophloes & $18.44(0.37)$ & $0.76(0.08)$ & $12.37(0.19)$ & $14.41(3.0)$ & $2.18(0.02)$ & $14.13(0.82)$ \\
\hline B. ungulata & $30.50(0.06)$ & $1.45(0.04)$ & $8.31(0.10)$ & $18.30(1.6)$ & $1.92(0.03)$ & $14.73(1.05)$ \\
\hline C. vitifolius & $25.11(0.11)$ & $1.81(0.11)$ & $24.48(0.53)$ & $8.91(0.28)$ & $3.05(0.04)$ & $27.44(0.56)$ \\
\hline
\end{tabular}

Table 5. Average leaf nutrient concentration $\left(\mathrm{g} \cdot \mathrm{kg}^{-1}\right)$ and N:P ratio for deciduous forest and other vegetation types.

\begin{tabular}{|c|c|c|c|c|c|c|}
\hline Vegetation type & $\mathrm{N}$ & $\mathrm{P}$ & K & $\mathrm{Ca}$ & $\mathrm{Mg}$ & $\mathrm{N}: \mathrm{P}$ \\
\hline Deciduous forest & 23.49 & 1.30 & 11.44 & 17.11 & 2.17 & 19.12 \\
\hline Savanna & 14.55 & 0.51 & 3.61 & 4.42 & 1.41 & 30.36 \\
\hline Gallery forest & 18.88 & 1.02 & 4.22 & 5.17 & 2.79 & 20.01 \\
\hline Semi-deciduous forest & 21.38 & 1.19 & 8.44 & 7.61 & 3.41 & 18.68 \\
\hline Primary rainforest & 14.00 & 0.24 & 5.23 & 7.41 & 2.81 & 58.98 \\
\hline Secondary rainforest & 20.77 & 1.57 & 9.63 & 11.50 & 2.93 & 13.23 \\
\hline "Terra Firme" forest & 17.50 & 0.76 & 8.15 & 2.84 & 1.16 & 23.03 \\
\hline "Igapó" forest & 17.30 & 0.62 & 8.88 & 8.72 & 2.3 & 27.90 \\
\hline "Várzea" forest & 25.40 & 1.31 & 10.90 & 17.70 & 4.00 & 19.39 \\
\hline
\end{tabular}



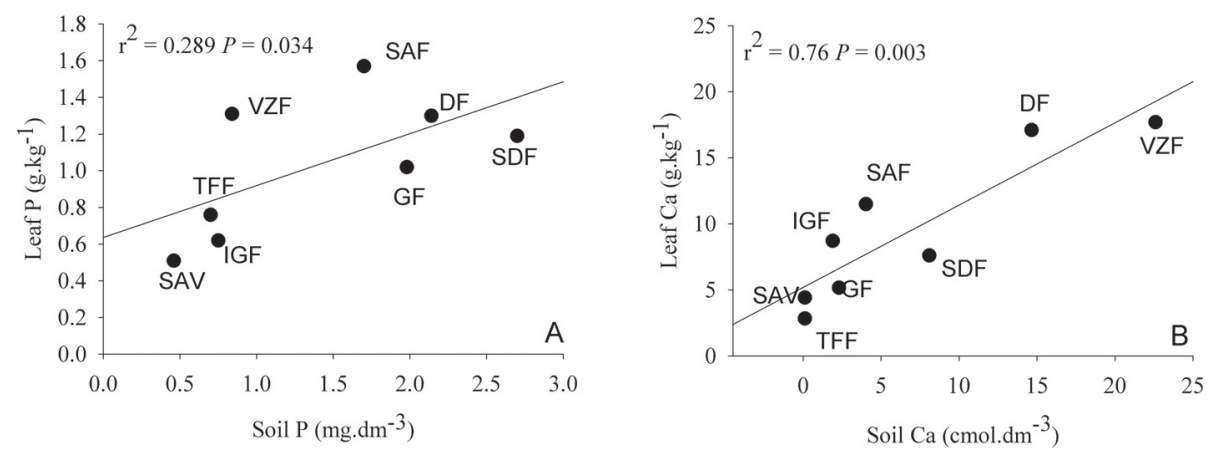

Figure 1. Relationships between soil P and leaf P concentration (A) and soil Ca and leaf Ca concentration (B) for systems studied. DF: deciduous forest; GF: gallery forest; IGF: "Igapó" forest; PAF: primary Atlantic rainforest; SAF: secondary Atlantic rainforest; SDF: semi-deciduous forest; SAV: savanna, TFF: "Terra Firme" forest; and VZF: "Várzea" forest.

Concerning the relationships between leaf nutrients of the evaluated systems, a common linear axis of variation was found in the relationship between $\mathrm{Ca}$ and $\mathrm{Mg}$ $\left(r^{2}=0.476, P=0.041\right)($ Fig. $2 \mathrm{~A})$ and between $\mathrm{Nand} \mathrm{P}\left(r^{2}=0.693\right.$, $P=0.001$ ) (Fig. 2B). The relationship between $\mathrm{Ca}$ and $\mathrm{Mg}$ was significant only when deciduous and "Várzea" forests were dropped out of the analysis (Fig. 2A); otherwise, the relationship was not significant $\left(r^{2}=0.322, P=0.105\right)$.

\section{Discussion}

\section{Edaphic aspects and leaf nutrient concentration}

We confirmed our hypothesis because deciduous forest had the higher leaf concentration of N, K, and $\mathrm{Ca}$ (Tab. 5) among the studied ecosystems. Secondary Atlantic rainforest is used for cacao plantations, which are fertilized (Sambuichi 2003); therefore, deciduous forests also had the highest $\mathrm{P}$ concentration of the systems studied (Tab. 5). The traditional assumption that plant nutritional status normally represents site fertility (Kimmins 2003) was confirmed at the community level for the studied Neotropical systems, at least for $\mathrm{Ca}$ and $\mathrm{P}$ (Fig. 1).

The limestone outcrops at the studied site belong to the Old Mesozoic/New Proterozoic era and are fundamentally formed by a parent material that has an elevated $\mathrm{Ca}$ and $\mathrm{Mg}$ content (Fernandes et al. 1982; Finatec 2001). These rocks occur scattered along the study site forming large blocks; however, small pieces of weathered limestone can be found together with an incipient black and highly fertile soil at some sites, which normally does not surpass $20 \mathrm{~cm}$ in depth (Felfili et al. 2007). As compared to the soil of other vegetations, these incipient soils are richer in macronutrients, particularly in terms of $\mathrm{Ca}, \mathrm{Mg}$, and $\mathrm{P}$ and also showed elevated values for organic matter and base saturation (Tab. 3).

The present soil condition of deciduous forest can explain the richer nutritional contents of the leaves of its species, at least for $\mathrm{P}$ and $\mathrm{Ca}$, because we found a positive and significant relationship between soil and leaf nutrient concentration (Fig. 1). The soil under deciduous forests is not well-developed and the parent materials are constantly suffering from physical (due to the strong seasonal aspect of the system) and biological weathering (roots of tree species grow between the rocks, breaking it) (Felfili et al. 2007). These factors allow the deciduous forests to receive a high annual input of macronutrients to be used in forest productivity and biomass accumulation (particularly, $\mathrm{Ca}$ and $\mathrm{Mg}$ ).

Soil nutrient content of deciduous forests was only comparable to that found for "Várzea" soils (Klinge et al. 1995), a vegetation type constantly affected by flooding. In the "Várzea" forest, the elevated nutrient content can be explained by an annual input derived from nutrient-rich sediments coming from the weathering of Andean rocks (Prance 1979; Junk 1993). Concerning the other forest types, the present soil nutrient availability is low; this can be explained by the fact that most of the soil nutrient content existing in the past is now stored in the forest biomass (Vitousek \& Sanford 1986; Haridasan 2000, 2001; Lilienfein et al. 2001). For savannas, the weathering in the past (Eiten 1972) and the frequent fires (which consume plant and litter biomass, releasing nutrients as ashes and smoke) (Coutinho 1979) may explain the low nutrient concentration found in its soil.

There was a strong and positive relationship between leaf $\mathrm{Ca}$ and leaf $\mathrm{Mg}$; a single axis of variation encompassed the studied vegetation types only when deciduous and "Várzea" forests were removed from the analysis (Fig. 2A). This result suggests that deciduous and "Várzea" forests possess unique stoichiometric relationships for these elements (McGroddy et al. 2004). This may be caused by elevated annual inputs of $\mathrm{Ca}$ and $\mathrm{Mg}$ from their weathering sources: the Andes for "Várzea" and limestone rocks for deciduous forests, while there is a lack of weathering sources providing $\mathrm{Ca}$ and $\mathrm{Mg}$ in the other systems studied (Vitousek \& Sanford 1986; Whitmore 1998). For the leaf N:P relationship, a single axis of variation encompassed all studied vegetations, with deciduous forests and the Atlantic rainforests being at opposite ends of the spectrum (Fig. 2B). The P supply for deciduous forests is continuous because of the supply stored in their soils (Table 3), whereas there is no weathering source and 

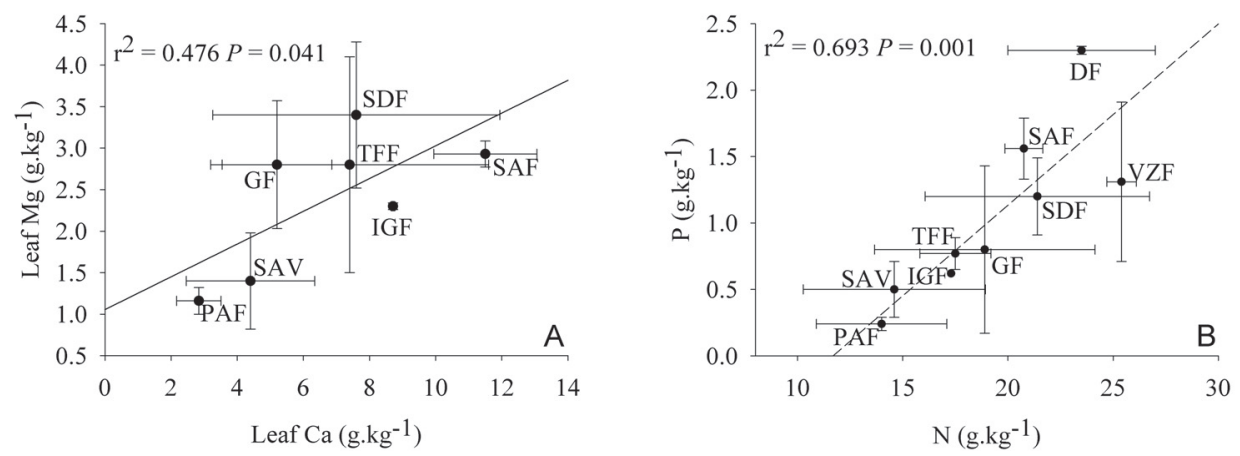

Figure 2. Relationships between leaf $\mathrm{Ca}$ and $\mathrm{Mg}$ concentration for systems studied (A) and relationship between leaf $\mathrm{N}$ and $\mathrm{P}$ concentration (B) for systems studied. DF: deciduous forest; GF: gallery forest; IGF: "Igapó" forest; PAF: primary Atlantic rainforest; SAF: secondary Atlantic rainforest; SDF: semi-deciduous forest; SAV: savanna, TFF: "Terra Firme" forest; and VZF: "Várzea” forest.

continuous loss of dissolved organic $\mathrm{P}$ for the Atlantic forests because of the elevated rainfall (Hedin et al. 1995).

The unique similarity found between deciduous forests and all the other systems studied is their similar N:P ratio; all of the studied systems suffered from $\mathrm{P}$ limitation because of their N:P ratios above 16 (Güsewell 2004). The exception is the secondary Atlantic rainforest, in which the $\mathrm{N}: \mathrm{P}$ ratio is lower than 16 . These results are in accordance with the expected commonly reported P limitation for a high number of Neotropical vegetation systems (Vitousek 1984; Bustamante et al. 2006). We found a certain degree of variability in the $\mathrm{N}: \mathrm{P}$ ratio of deciduous trees species; however, most species show values higher than 16 . Interestingly, five species in this system, of which four (Tabebuia, Pseudobombax, Sterculia, and Myracruodon) are the major common and phytosociologically dominant species (Felfili et al. 2007), showed no limitation for $\mathrm{P}$ or for $\mathrm{N}$ (N:P ratios around 15). This finding points to a high spatial variability in local P limitation because the sampled soils soil have higher values of $\mathrm{P}$ availability (Tab. 3 ).

\section{The role of nutrients on the ecophysiology of deciduous forest species}

Ca plays an important role in forest productivity, particularly in plant growth (McLaughlin \& Wimmer 1999), because plants in environments limited in Ca can respond to its addition (Villela \& Haridasan 1994). Because of their higher leaf $\mathrm{Ca}$ concentration, deciduous forest species are able to accumulate it in leaf tissues, thus forming diverse types of Ca crystals (Somavilla et al. 2014). This accumulation of Ca may serve as a source of Ca during the process of water regulation, particularly for osmotic purposes (Ghanem et al. 2010).

Foliar $\mathrm{N}$ and $\mathrm{P}$ concentration are related to the content of chlorophyll and carboxilation enzymes, which are intrinsically linked to photosynthetic demand (Duursma \& Marshall 2006) and, therefore, influenced by light availability. The higher $\mathrm{N}$ concentration found in deciduous forest trees coupled with the high values of specific leaf area (Somavilla et al. 2014) may indicate elevated carbon assimilation and productivity because these systems are not limited by light (Baker et al. 2003; Poorter 2008; Somavilla et al. 2014). Deciduous forest trees on these limestone outcrops maintain their canopy without leaves for a period of 5-6 months during the dry period (Carvalho 2009). This situation shows that productivity may be restricted to the few months when water is available. The coupling of higher values of specific leaf area (Somavilla et al. 2014) and elevated N and P concentrations may be a strategy to perform substantial carbon assimilation and growth in this short period (Hoffmann et al. 2005; Poorter 2008; Gotsch et al. 2010).

$\mathrm{K}$ achieves the highest values among the studied vegetations in dry forest trees (Tab. 5). Its concentration in deciduous forest tree species can be three times higher than that found in savannas (which are constantly prone to fire and may lose significant amounts of $\mathrm{K}$ ) and two times higher than in wet forests (Tab. 5). This suggests that $\mathrm{K}$ is playing an important role in water level regulation in these species, particularly in stomata control, because these plants keep their leaves active during the first 2-3 months in the dry season. In addition, all of the studied species possess mucilaginous substances in their leaf cells (Somavilla et al. 2014), including in some guard cells of stomata. Mucilaginous substances in cells can serve as means of water storage, thus demanding high amounts of $\mathrm{K}$ ions to produce the expected control (Ghanem et al. 2010). The foliar K concentration can also play an important role in osmotic regulation in the trunks of some species: C. arborea, for example, is a tree with low wood density that can store water in its trunk as an adaptive strategy to low water availability (Rojas-Jiménez et al. 2007).

\section{Leaf nutrients and their implication for dry forest management and conservation}

The assessment of leaf nutritional status can bring important and essential information for direct actions in the conservation of species (Sariyildsz \& Anderson 2005). In deciduous forests on limestone outcrops, special attention has to be given to Ca because it is very abundant in soils and 
in the leaves of tree species. Ca is proposed as an important nutrient for biomass accumulation and plant growth, thus acting in important steps in the metabolism of cells, including carbon fixation. Based on Ca leaf content, Hou \& Merkle (1950) classified plants into two groups: the calcicole (leaf concentration between 15.7 and $22.7 \mathrm{~g} \cdot \mathrm{kg}$ ) and the calcifugous (with leaf concentration between 4.8 and $10.8 \mathrm{~g} \cdot \mathrm{kg}$ ). Based on this criterion, 8 of the 12 studied species can be considered calcicole. This fact deserves special attention, particularly in the production of seedlings with the purpose of forest restoration, because these species may not be able to establish and grow under low Ca availability in the soil.

The selective extraction of rocks to produce cement for urban constructions and calcarium to correct soil $\mathrm{pH}$ for crop production (Felfili 2003) could bring significant changes in this type of forest not only because it demands heavy machinery but also because it can bring significant changes in nutrient cycles and rock weathering patterns. Because of the intrinsic relationships between $\mathrm{Ca}$ and $\mathrm{Mg}$ and $\mathrm{N}$ and $\mathrm{P}$, small changes in soil conditions could lead to an imbalance in nutrient relationships for tree species in this type of forest. The most affected should be species showing balanced N:P ratios (ratio around 15, as Myracrodruon urundeuva, Pseudobombax tomentosum and Sterculia striata).

\section{Conclusions}

Among the ecosystems studied, deciduous forests have the highest nutrient content of elements such as $\mathrm{Ca}$ and $\mathrm{Mg}$ either in soils or leaves. This demonstrates that eutrophic soils, associated with severe seasonal aspects such as long drought, could have filtered species able to store nutrients and use these available resources (before losing their leaves) to resist the drought, thus supporting a eutrophic ecosystem even in harsh abiotic conditions.

\section{Acknowledgments}

DRR thanks CNPq for financial support (Grant 141624/2009-4). FAC thanks Fundação O Boticário de Proteção à Natureza (Project no 0705_20061) and CNPq (Grant 476477/2006-9) for financial support. We thank the technician Maria Rubia for her help in nutrient analysis.

\section{References}

Aerts R, Chapin III FS. 2000. The mineral nutrition of wild plants revisited: Are-evaluation of processes and patterns. Advances in Ecological Research 30: 1-67.

Allen SE, Grimshaw HM, Parkinson JA, Quarmby C. 1974. Chemical analysis of ecological materials. Oxford, Blackwell Scientific Publications.

Araújo GM, Haridasan M. 1988. A comparison of the nutritional status of two forest communities on mesotrophic and dystrophic soils in Central Brazil. Communications in Soil Science and Plant Analysis 19: 1075-1089.
Baker TR, Swaine MD, Burslem DFRP. 2003. Variation in tropical forest growth rates: combined effects of functional group composition and resource availability. Perspectives in Plant Ecology, Evolution and Systematics 6: 21-36.

Boeger MRT, Wisniewski C, Reissmann CB. 2005. Nutrientes foliares de espécies arbóreas de três estádios sucessionais de floresta ombrófila densa no sul do Brasil. Acta Botanica Brasilica 19: 167-181.

Bustamante MMC, Medina E, Asner GP, Nardoto GB, Garcia-Montiel DC. 2006. Nitrogen cycling in tropical and temperate savannas. Biogeochemistry 79: 209-237.

Carvalho FA. 2009. Dinâmica da vegetação arbórea de uma floresta estacional decidual sobre afloramentos calcários no Brasil Central. PhD. Thesis. University of Brasilia, Brazil.

Coutinho LM. 1979. Aspectos ecológicos do fogo no cerrado. III. A precipitação atmosférica de nutrientes mineiras. Revista Brasileira de Botânica 2: 97-101.

Duursma RA, Marshall JD. 2006. Vertical canopy gradients in delta C-13 correspond with leaf nitrogen content in a mixed-species conifer forest. Trees 20: 496-506.

Eiten G. 1972. The cerrado vegetation of Brazil. Botanical Review 38: 201-341.

EMBRAPA - Empresa Brasileira de Pesquisa Agropecuária. 1997. Manual de métodos de análise de solo. 2nd. edn. Rio de Janeiro, Centro Nacional de Pesquisa do Solo.

Felfili JM. 2003. Fragmentos de florestas estacionais do Brasil Central: diagnóstico e proposta de corredores ecológicos. In: Costa RB. (ed.) Fragmentação florestal e alternativas de desenvolvimento rural na Região Centro-Oeste. Campo Grande, Universidade Católica Dom Bosco. p. 195-263.

Felfili JM, Nascimento ART, Fagg CW, Meirelles EM. 2007. Floristic composition and community structure of a seasonally deciduous forest on limestone outcrops in Central Brazil. Revista Brasileira de Botânica 30: 611-621.

Fernandes PECA, Montes ML, Braz ERC. 1982. Geologia. In: Projeto RADAMBRASIL. Levantamento de Recursos Naturais. Folha SD.23 Brasília. Rio de Janeiro, Projeto Radambrasil. p. 25-204.

Finatec. 2001. Inventário Hidrelétrico da bacia do rio Paranã. Mapas de vegetação, solos e geologia. Brasília, Finatec/Agência Nacional de Energia elétrica.

Furley PA. 2007. Tropical savannas and associated forests: vegetation and plant ecology. Progress in Physical Geography 31: 203-211.

Furley PA, Newey WW. 1979. Variations in plant communities with topography over tropical limestone soils. Journal of Biogeography 6: 1-15.

Furley PA, Ratter JA. 1988. Soil Resources and Plant Communities of the Central Brazilian Cerrado and Their Development. Journal of Biogeography 15: 97-108.

Ghanem ME, Han RM, Classen B, et al. 2010. Mucilage and polysaccharides in the halophyte plant species Kosteletzkya virginica: Localization and composition in relation to salt stress. Journal of Plant Physiology 167: 382-392.

Gotsch SG, Powers JS, Lerdau MT. 2010. Leaf traits and water relations of 12 evergreen species in Costa Rican wet and dry forests: patterns of intra-specific variation across forests and seasons. Plant Ecology 211: 133-146.

Güsewell S. 2004. N:P ratios in terrestrial plants: variations and functional significance. New Phytologist 164:243-266

Hardtle W, Oheimb G, Westphal C. 2005. Relationships between the vegetation and soil conditions in beech and beech-oak forests of northern Germany. Plant Ecology 177: 113-124.

Haridasan M. 2000. Nutrição mineral de plantas nativas do cerrado. Revista Brasileira de Fisiologia Vegetal 12: 54-64.

Haridasan M. 2001. Nutrient cycling as a function of landscape and biotic characteristics in the cerrado of central Brazil. In: McClain ME, Victoria RL, Richey JE. (eds). Biogeochemistry of the Amazon basin and its role in a changing world. Oxford, Oxford University. p. 68-83.

Haridasan M. 2008. Nutritional adaptations of native plants of the cerrado biome in acid soils. Brazilian Journal of Plant Physiology 20: 183-195.

Haridasan H, Araújo GM. 2005. Perfil nutricional de espécies lenhosas de duas florestas semidecíduas em Uberlândia, MG. Revista Brasileira de Botânica 28: 295-303. 
Hedin LO, Armesto JJ, Johnson AH. 1995. Patterns of nutrient loss from unpolluted, old-growth, temperate forests: evaluation of biogeochemical theory. Ecology 76: 493-509.

Hoffmann WA, Franco AC, Moreira MZ, Haridasan M. 2005. Specific leaf area explains differences in leaf traits between congeneric savanna and forest trees. Functional Ecology 19: 932-940.

Hou HY, Merkle FG. 1950. Chemical composition of certain calcifugous and calcicole plants. Soil Science 69: 471-486.

Junk WJ. 1993. Wetlands of tropical South-America. In: Whigham D, Hejny S, Dykyjova' D. (eds.) Wetlands of the world. Kluve, Dordrecht. p. 679-739.

Kimmins JP. 2003. Forest ecology: a foundation for sustainable forest management and environmental ethics in forestry, 3rd. edn. Prentice Hall.

Klinge H, Adis J, Worbes M. 1995. The vegetation of a seasonal várzea forest in thelower Solimões river, Brazilian Amazonia. Acta Amazonica, 25:201-220.

Klinge H, Furch K, Harms E, Revilla J. 1983. Foliar nutrient levels of native tree species from Central Amazonia. I. Inundation forests. Amazoniana 8: 19-45.

Lilienfein J, Wilcke W, Zimmermann R, Gerstberger P, Araújo GM, Zech W. 2001. Nutrient storage in soil and biomass of native Brazilian Cerrado. Journal of Plant Nutrition and Soil Science 164: 487-495.

McGroddy ME, Daufresne T, Hedin LO. 2004. Scaling of C:N:P stoichiometry in forests worldwide: implications of terrestrial Redfield-Type ratios. Ecology 85: 2390-2401.

McLaughlin SB, Wimmer R. 1999. Calcium physiology and terrestrial ecosystem processes. New Phytologist 142: 373- 417.

Miles L, Newton AC, DeFries RS, et al. 2006. A global overview of the conservation status of tropical dry forests. Journal of Biogeography 33: 491-505.

Mooney HA, Bullock SH, Medina E. 1995. Introduction. Seasonally dry tropical forests. In: Bullock SH, Mooney HA, Medina E. (eds.) Cambridge, Cambridge University Press. p. 1-8.

Morellato LPC, Haddad CFB. 2000. Introduction: The Brazilian Atlantic Forest. Biotropica 32: 786-792.

Moreno MIC. 2005. Estrutura fitossociológica, estado nutricional de espécies arbóreas e fertilidade do sol em diferentes fitofisionomias de cerrado e de matas na região do Triângulo Mineiro. PhD. Thesis. University of Brasilia, Brazil.

Nogueira PE, Haridasan M. 1997. Foliar nutrient concentrations of tree species in four gallery forests in central Brazil. In: Encinas JI, Kleinn C. (eds.) Proceedings of the International Symposium on Assessment and Monitoring of Forests in Tropical Dry Regions with Special Reference to Gallery Forests. Brasília, Universidade de Brasília. p.309-321.

Oliveira-Filho AT, Jarenkow JA, Rodal MJN. 2006. Floristic relationships of seasonally dry forests of eastern South America based on tree species distribution patterns. In: Pennington RT, Ratter JA, Lewis GP. (eds.) Neotropical savannas and dry forests: Plant diversity, biogeography and conservation. The Systematics Association Special volume Series 69, Boca Raton, CRC Press - Taylor and Francis Group. p. 159-192.

Pennington RT, Lewis GP, Ratter JA. 2006. An overview of the plant diversity, biogeography and conservation of Neotropical savannas and seasonally dry forests. In: Pennington RT, Lewis GP, Ratter JA (eds.) Neotropical savannas and dry forests: diversity, biogeography and conservation. The Systematics Association Special Volume Series 69. London, CRC Press. p. 1-29.

Pennington RT, Lavin M, Oliveira-Filho AT. 2009. Woody plant diversity, evolution and ecology in the tropics: perspectives from seasonally dry tropical forests. Annual Review of Ecology, Evolution and Systematics 40: 427-457.

Pires JM, Prance GT. 1985 The vegetation types of the Brazilian Amazon. In: Prance GT, Lovejoy TE. (eds.) Key environments: Amazonia. Pergamon Press. p. 109-145.

Poorter L. 2008. Leaf traits show different relationships with shade tolerande in moist versus dry tropical forests. New Phytologist 181: 890-900.

Prance GT. 1979. Notes on the vegetation of Amazonia III. The terminology of Amazonian forest subject to inundation. Brittonia 31: 26-38.

Ribeiro JF, Walter BMT. 2008. Fitofisionomias do Bioma Cerrado. In Sano S, Almeida SP, Ribeiro JF. (eds.) Cerrado: Ecologia e flora. Planaltina, EMBRAPA Cerrados. p. 19-45.

Rojas-Jiménez K, Holbrook NM, Gutiérrez-Soto MV. 2007. Dry-season leaf flushing of Enterolobium cyclocarpum (ear-pod tree): above- and belowground phenology and water relations. Tree Physiology 27: 1561-1568.

Rossatto DR, Takahashi FSC, Silva LCR, Franco AC. 2010. Características funcionais de folhas de sol e sombra de espécies arbóreas em uma mata de galeria no Distrito Federal, Brasil. Acta Botanica Brasilica 24: 640-647.

Rossatto DR, Hoffmann WA, Silva LCR, Haridasan M, Sternberg LSL, Franco AC. 2013. Seasonal variation in leaf traits between congeneric savanna and forest trees in Central Brazil: implications for forest expansion into savanna. Trees 27: 1139-1150.

Sambuichi RHR. 2003. Ecologia da vegetação arbórea de cabruca - Mata Atlântica raleada utilizada para cultivo de cacau - na região sul da Bahia. PhD. Thesis. University of Brasilia, Brazil.

Sanchez-Azofeifa A, Calvo J, Espirito Santo MM, Fernandes GW, Powers J, Quesada M. 2013. Tropical Dry Forests in the Americas: The Tropi-Dry Endeavour. In: Sanchez-Azofeifa A, Powers J, Fernandes GW, Quesada M. (eds.) Tropical Dry Forests in the Americas: Ecology, Conservation, and Management. Boca Raton, CRC Press. p. 1-16.

Sariyildiz T, Anderson JM. 2005. Variation in the chemical composition of green leaves and leaf litters from three deciduous tree species growing on different soil types. Forest Ecology Management 210: 303-319.

Silva JF, Fariñas MR, Felfili JM, Klink CA. 2006. Spatial heterogeneity, land use and conservation in the cerrado region of Brazil. Journal of Biogeography 33: 536-548.

Somavilla N, Kolb RM, Rossatto DR. 2014. Leaf anatomical traits corroborate the leaf economic spectrum: a case study with deciduous forest tree species. Brazilian Journal of Botany 37: 69-82.

Villela DMV, Haridasan M. 1994. Response of the ground layer community of a cerrado vegetation in central Brazil to liming and irrigations Plant Soil 163: 25-31.

Vitousek PM. 1984. Litterfall, nutrient cycling, and nutrientlimitation in tropical forests. Ecology 65: 285-98.

Vitousek PM, Sanford RLJ. 1986. Nutrient cycling in moist tropical forest. Annual Review of Ecology and Systematics 17: 137-167.

Whitmore TC. 1998. An introduction to tropical rain forests. Oxford, Oxford University Press.

Wright IJ, Reich PB, Westoby M, et al. 2004. The worldwide leaf economics spectrum. Nature 428: 821-827.

Wright IJ, Ackerly DD, Bongers F, et al. 2007. Relationships among ecologically important dimensions of plant trait variation in seven Neotropical forests. Annals of Botany 99: 1003-1015.

Zar JH. 2010. Biostatistical analysis. 5th. edn. Upper Saddle River, Prentice Hall. 